\title{
Kecenderungan dalam Implementasi Otonomi Daerah
}

\author{
Bambang Setiaji
}

The result of autonomous region has not an obvious vision, even hegemony and collusion between local government and district and municipal elected representative assemblies have been growing. It has needed precise autonomous region functions (stabilization, distribution and economics resources allocation) and improving public services and district investment.

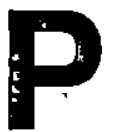

ada tahun-tahun awal implementasi otonomi daerah tentu perlu evaluasi agar pelaksanaan otonomi mendapatkan feedback untuk selalu berada pada track yang semestinya. Tujuan terpenting dari otonomi daerah adalah mendemokrasikan pilihan publik. Dengan otonomi daerah dimungkinkan pilihan publik lebih dapat menangkap kehendak rakyat, sedangkan dalam pemerintahan yang tersentral, pemenintah menjadi monopoli yang seolah lebih mengetahui apa yang dibutuhkan oleh rakyat.

Tujuan yang mulia tersebut tidaklah tanpa masalah. Bersamaan dengan reformasi politik; pengalihan wewenang ke daerah dilaksanakan dalam situasi hiruk pikuk perubahan. Masa perubahan dari suatu keseimbangan kepada keseimbangan yang lain atau dari suatu order ke order yang lain adalah masa banyak celah dan lubang. Celah dan lubang dimungkinkan dimanfaatkan secara kurang bertanggung jawab. Namun, masalah celah dan lubang adalah masalah jangka pendek yang tidak dapat menghilangkan manfaat otonomi berupa pendemokrasian pilihan publik yang lebih mendasar, sehingga tidak dapat menjadi alasan untuk mengembalikannya kepada bentuk terpusat

Otonomi daerah memerlukan perubahan paradigma pemerintahan daerah,dari semula sebagai tangan panjang birokrasi pemeritah pusat yang pada waktus itu semata menyandarkan kepada otoritas kekuasaan, menjadi pemerintahan daerah yang merupakan sarana menggalang partisapasi dalam memenuhi barang dan jasa publik yang menjadi kebutuhan hidup bersama. Pemerintah daerah yang ideal adalah pemerintah daerah yang mampu menjadi mediator dan mampu membangkitkan partisipasi masyarakat dalam memenuhi kebutuhan publik tersebut. 
Wujud dari partisipasi yang paling kuantitatif adalah membayar pajak. Namun demikian pajak yang dapat dipungut di daerah hanya terbatas kepada pajak properti tentama PBB dan user charge atau retribusi. PBB pun tidak dikembangkan menjadi. pajak properti yang lebih detail dan beragam, baik harta kekayaan bergerak maupun harta tidak bergerak. Di negara maju, khususnya di Amerika Serikat daerah diberi hak dalam proporsi yang kecil untuk memungut pajak penapatan (income taxes), pajak penjualan (sales dan excise taxes), di samping pajak properti. Hal tersebut dapat meningkatkan partisipasi di daerah, dan dapat menjadi cross check yang justru akan meningkatkan penerimaan pajak di Pusat.

Dengan keterbatasan otonomi daerah seperti di atas, tulisan ini memusatkan kepada dua hal pokok, yaitu kecenderungan yang ditandai oleh bibit-bibit salah track dari aplikasi otonomi daerah. Selanjutnya, paper ini akan membahas usulan-usulan untuk meningkatkan fungsi pemerintah daerah dalam ikut menanggulangi persoalan utama dewasa ini yaitu adanya pengangguran dan kemiskinan (social welfare), di samping tugas pemerintah daerah yang lain terutama dalam bidang pendidikan, kesehatan, sosial; dan transportasi.

\section{Demokratisasi vs Konspirasi}

Sejauh yang diamati di beberapa daerah, fungsi otonomi sebagai cara mendemokrasikan pilihan publik dalam pembangunan daerah menghadapi konspirasikonspirasi yang memiliki kepentingan tersendiri. Dengan otonomi daerah pilihan publik akan terumuskan lebih transparan, misalnya melalui voting di DPRD terhadap alternatif-alternatif proyek pembangunan. Setiap pilihan bentuk dan jenis proyek berimplikasi kepada apa, bagaimana, dan kepada siapa manfaat proyek ditujukan.
Misalnya membangun pasar dengan bentuk tradisional dan bentuk plaza yang modern berimplikasi kepada apa yang dijual, bagaimana dijual, siapa yang berkontribusi, dan siapa yang menjadi penjual dan pembeli. Di Surakarta kasus alternatif tiga pilihan dalam pembangunan Pasar Gede menjadi contoh kasus dalam hal tersebut.

Dalam kasus Pasar Gede Surakarta, DPRD cenderung kepada bentuk modern. Hal tersebut menimbulkan protes dari rakyat, dan dengan itu akhimya bentuk tradisional memenangkan voting. Dengan kemenangan bentuk tradisional, proyek itu sekarang tetap menjadi peluang kontribusi usaha kecil menengah (UKM). Cara membuat altematif terlihat baik jika dijadikan pola dalam setiap pembangunan di daerah karena dengan itu terjadi transparansi mengenai apa yang dibangun dan untuk siapa dibangun.

Pola demokratisasi ini umumnya menghadapi lawan berupa pola konspirasi. Konspirasi adalah pola memonopoli pilihan publik, yaitu, pemerintah (merasa) lebih tahu dari apa yang dibutuhkan rakyat sehingga dengan berbagai cara menghindari bentuk pilihan menjadi bentuk kompromi, atau kolusi antara pemerintah daerah dan. DPRD. Salah satu asumsi dari UU otonomi adalah antara DPRD dan pemerintah tidak ada cheap talk, sehingga DPRD akan berfungsi sebagai pengawas pemerintah. Kedua lembaga berada dalam game berkompetisi. Dengan adanya cheap talk (kong kalikong), maka sistem pengawasan dan kompetisi yang dibangun oleh semangat UU otonomi menjadi hilang. Jika kedua lembaga itu cheap talk maka rakyat akan berada di bawah monopoli, di mana rakyat didikte dalam mengalokasi barang publik.

\section{Kolusi}

Kini hubungan antara, DPRD dan eksekutif cenderung kepada dua kutub. Kutub 
yang pertama, bersifat hegemoni atau monopoli, misalnya DPRD Surabaya yang semena mena memecat Walikota. Kutub yang lain adalah hubungan yang bersifat kolusi. Tidak jarang hubungan yang keras antara keduanya juga berakhir dengan tujuan kolusi. Kolusi adalah keadaan jika dua agen yang seharusnya bersaing mengadakan cheap talk yang bertujuan memonopoli rakyat banyak (Tirole,1989). Jika kolusi terjadi maka umumnya rakyat yang dirugikan. Húbungan antara DPRD dan eksekutif menurut designnya adalah kompetitif atau saling bersaing secara sehat. Dalam hubungan yang bersaing secara sehat maka rakyat akan diuntungkan.

Baik hubungan yang hegemonik dan kolutif terlihat bervariasi di berbagai daerah. Terdapat DPRD yang keras, terdapat juga komisi yanǵ memperjuangkan Dinas-Dinas partnernya secara berlebihan dalam penyusunan anggaran, sehingga menimbulkan tanda tanya. Sekarang beredar istilah anggaran titipan, yaitu bagian DPRD jika dapat menggolkan anggaran dinas tertentu. Kasus anggaran APBD Rp 25 milyar di Jabar yang dialokasikan untuk pembeliañ tanah DPRD, senada dengan itu kasus sepeda motor yang dibagikan kepada DPRD Sukoharjo adalah dua hal yang kebetulan mencuat. Pola ini bisa jadi merupakan pola umum yang meluas. Jika benar demikian, maka menunjukkan betapa rencangan sistem saling mengontrol yang sehat tidak berjalan lagi, dan hal ini mendorong munculnya lembaga kontrol ketiga yang langsung dari masyarakat yang cenderung jalanan dan penuh rumor.

\section{Bias PAD dan Pembangunan}

Bias terhadap PAD sudah ditengaraikan oleh banyak ahli sejak awal otonomi daerah (Darmawan, 2000). Orientasi pemerintah untuk memperbesar APBD adalah baik, jika hal itu bertujuan untuk membangun dan memenuhi kebutuhan publik rakyat yang urgen, atau lebih dari itu jika bertujuan menghidupkan ekonomi rakyat. Hal ini akan tercermin dari komposisi anggaran rutin dan pembangunan. Masih terdapat pemborosan yang cenderung unaccountable terhadap besamya proporsi dana nutin, walaupun tidak menjamin bahwa anggaran pembangunan bersih dari kebocoran.

Sistem yang berlaku terlihat juga belum sehat, setelah pemerintah pusat memonopoli sumber-sumber pajak yang penting (yaitu pajak pendapatan, PPN dan cukai, dan pajak perseroan) maka yang tersisa adalah pajak properti (PBB) yang masih tradisional, dan beberapa user charge, kontirbusi langsung atas penggunaan barang publik seperti retribusi, pajak wisata, iklan daerăh, dan sebagainya. Sumber PAD yang terbatas ini mendorong daerah untuk mengekploitasi sedemikian rupa tanpa analisis yang memadai dampaknya terhadap ekonomi rakyat. Pungutan-pungutan langsung yang menyangkut transportasi, dan iklan di daerah mungkin sudah menurunkan gairah bisnis yang pada akhirnya menurunkan kesempatan kerja di daerah suatau hal yang lebih penting daripada PAD itu sendiri. Karena pendpatan DPRD juga tergantung dari besamya PAD, maka sistem ini potensial menimbulkan kolusi eksekutif legislatif. Dampak dari sistem itu adalah menurunnya gairah bisnis dan penyerapan tenaga kerja di daerah.

Kelemahan di atas disebabkan oleh dua hal, yaitu, pengetahuan dari SDM pelaku yang kurang memadai, dan yang lebih penting dari itu, moralitas berupa kesadaran dan ketulusan pengabdian kepada rakyat juga kurang. Bias PAD ditemukan dalam hampir setiap pemeritah kota dan DPRD. Pemerintah kota yang memiliki PAD besar mendapat tempat tersendiri dalam pergaulan antar pemerintah daerah. Akan tetapi, pe- 
ngetahuan bahwa PAD mungkin mengganggu kegiatan ekonomi kurang dipahami, dan sebaliknya bahwa PAD dapat diarahkan untuk kembali menghidupkan ekonomi rakyat juga kurang dipahami.

Perilaku SDM pemerintahan di beberapa daerah di Jawa Tengah yang diamati, belum memperlihatkan suatu concem yang benar-benar memikirkan kemajuan daerah, misalnya jika diukur dengan pemerintahan daerah yang digambarkan Osborne dan Plastrik (2000) atau tulisan sebelumnya Osborne dan Gaebler, (1999). Dalam dua buku itu digambarkan pemahaman pemerintah daerah dalam memenuhi kebutuhan yang urgen dari rakyatnya, misalnya membuat pendidikan yang bermutu sambil mengatasi daerah yang secara sosial buruk, dan digambarkan pula spirit efisiensi (misalnya perlakuan terhadap sisa anggaran yang boleh di simpan, dan bukannya dihabis-habiskan), demikian juga tergambar efektvitas dengan memangskan prosedur borokrasi.

Orientasi atas penggalian penerimaan baik PAD maupun lobi ke Pusat, masih berorientasi kepada kemuliaan pemerintah daerah dan DPRD itu sendiri. Tidak ditemukan pemerintah daerah yang berorientasi pemecahan masalah dalam menanggapi pengangguran dan kemacetan sektor riel dewasa ini. Bahkan, orientasi konvensionalpun seperti untuk memajukan pendidikan di daerah, memajukan pelayanan kesehatan, dan mengurusi masalah sosial (pengurangan kemiskinan), sangat kurang.

Hubungan antara pemerintah kota dan rakyat sebagaimana digambarkan oleh Osborne dan Gaebler (1999) justru ditemukan pada tingkat Rukun Tetangga (RT). Pemecahan masalah kebutuhan barang publik di tingkat RT di kota-kota seperti pengerasan jalan kampung, pembangunan pos dan penanganan sampah berjalan dengan baik. Partisipasi sebagaimana yang terjadi di RT dalam pengadaan barang publik, menjadi menghilang di tingkat pemerintah formal. Hal ini disebabkan tidak adanya kepercayaan rakyat pada dua hal pokok. Pertama, rakyat tidak percaya bahwa pemerintah daerah memiliki spirit dalam memajukan daerahnya, misalnya, mengadakan pendidikan yang baik bagi semua segmen masyarakat dari yang mampu sampai yang tinggal di daerah kumuh. Kedua, rakyat belum percaya akuntabilitasnya. Suatu entitas disebut accountable jika mampu menyajikan informasi secara terbuka mengenai keputusankeputusan yang telah diambil selama beroperasinya entitas tersebut, memungkinkan pihak luar (misalnya legislatif, auditor, atau masyarakat secara luas) mereview informasi tersebut, serta bila dibutuhkan harus ada kesediaan untuk mengambil tindakan korektif, (Nurkholis).

Dalam pembangunan daerah, terlihat pemerintah daerah cenderung menyukai hiruk-pikuk yang secara visual menjadi lambang kemajuan kota yang bias dan keripos seperti membangun pusat perbelanjaan dan taman kota daripada proyekproyek vital yang subtantif dalam memajukan rakyat seperti pendidikan untuk berbagai segmen masyarakat sambil mengatasi kondisi sosial yang buruk, layanan kesehatan, dan kesejahteraan sosial (terutama mengangkat pengangguran kota yang begitu gawat). Pos-pos APBD yang didomniasi oleh anggaran rutine dan anggaran pembangunan yang bias tidak mungkin dapat mendorong kepercayaan rakyat.

Sebaliknya, anggaran administrasi yang sangat menonjol mencerminkan betapa pemrintah daerah hanya berorientasi kepada kemuliaan atau prestige dan birokrasinya sendiri. Bandingkan dua anggaran pada dua tabel berikut. 
Topik: Kecenderungan dalam Implementasi Otonomi Daerah, Bambang Setiaji

Tabel 1

Rata-rata Pengeluaran Pemerintah Daerah

di Amerika Serikat (1991)

\begin{tabular}{|l|c|}
\hline \multicolumn{1}{|c|}{ Pos Pengeluaran } & Persentase \\
\hline Pendidikan & 39,9 \\
Kesehatan & 7,9 \\
Kesejahteraan publik (public welfare) & 5,0 \\
Transportasi & 5,0 \\
Perumahan dan lingkungan & 11,1 \\
Polisi dan pemadam kebakaran & 7,7 \\
Bunga hutang & 5,3 \\
Admisnistrasi & 5,4 \\
Lainnya & 9,5 \\
Jumlah & 100 \\
\hline
\end{tabular}

Sumber: Fisher, 1996. State and local public finance. p. 14. 
Topik: Kecenderungan dalam Implementasi Otonomi Daerah, Bambang Setiaji

Tabel 2

Anggaran Pengeluaran Daerah Kabupaten Sukoharjo, 2001

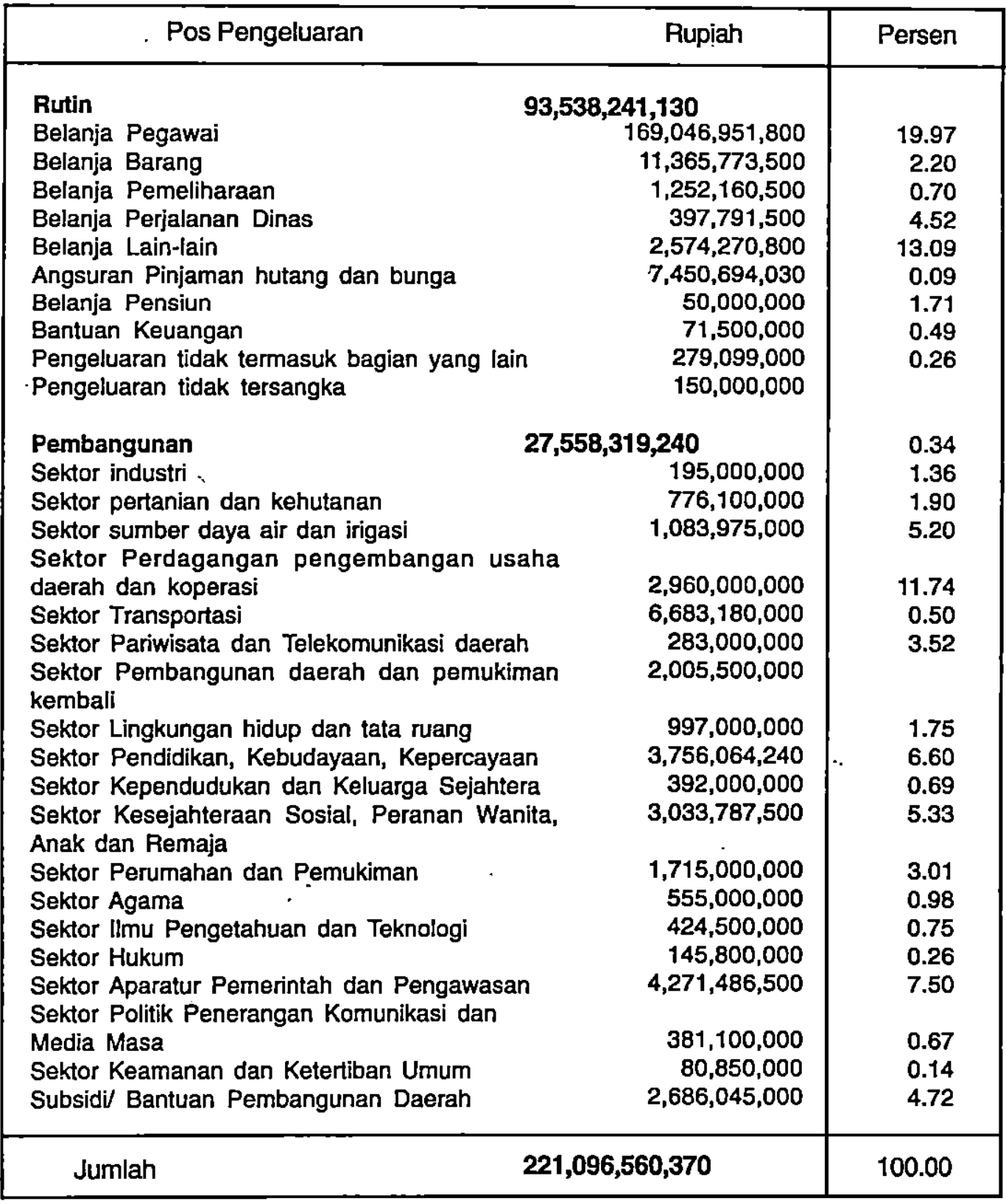

") nilai persentase dari total pengeluaran rutin dan pembangunan di luar belanja pegawai. Sumber: diolah dari www. Sukoharjo.go.id. 
Apa yang dapat diambil dari kedua tabel tersebut di atas antara lain, di negara maju khususnya AS anggaran pemda terlihat fokus. Di samping nominalnya besar anggaran terfokus kepada 4 pilar utama fungsi pemerintah daerah yaitu pendidikan, kesehatan, kesejahteraan sosial, dan transportasi. Sebaliknya di Indonesia, dengan kasus Sukoharjo, anggaran terlihat tidak terfokus. Anggaran cenderung kepada administrasi dan membiayai birokrasi itu sendiri. Anggaran yang berupa pelayanan rakyat langsung sangat rendah. Dengan perilaku pemerintah yang berorientasi kepada dirinya sendiri sebagaimana dicerminkan oleh data di atas, sangat sulit kiranya memperoleh kepercayaan rakyat.

Pada era krisis, langkah pertama yang harus dikerjakan semestinya membangun kepercayaan rakyat. Dengan demikian membangun komitmen adalah yang terpenting. Salah satu cara membangun komitmen dari kepeloporan pemerintah adalah income cutting, misalnya melakukan pemotongan gaji, penghematan biaya adminsitrasi, pengurangan perjalan dinas dan sebagainya. Semuanya ini bertujuan agar pemerintah daerah mampu melakukan pelayanan langsung dalam bidang pendidikan, kesehatan, kelaparan, dan kemiskinan.

Sebaliknya, yang ditemukan di lapangan bukannya income cutting, melainkan income seeking. Hal ini terlihat dari tingginya gaji DPRD yang di beberapa daerah sebesar 4 kali gaji guru besar. Banyak pejabat publik melakukan moral hazard berupa tindakan hit \& run atau berperilaku seperti petruk dadi ratu. Kejadian ini mirip dengan mentalitas para penjual di terminal manakala mengetahui tidak akan berjumpa kembali dengan pembeli, si penjual memberikan harga yang sangat tinggi. Perilaku seperti itu terlihat dari keputusan menetapkan gaji tinggi, menyusun anggaran yang menguntungkan diri sendiri, dan sebagainya. Perlu dicatat bahwa gaji pegawai negeri adalah yang tertinggi dibanding dengan gaji di berbagai industri swasta (Manning, 1994). Alasan menetapkan gaji tinggi untuk menyamai swasta adalah mitos yang diciptakan untuk melakukan moral hazard.

\section{Proposal}

Dengan kemungkinan yang didiskusikan di atas, maka usulan berikut diajukan.

a. Menajamkan fungsi pemerintah daerah. Dalam era liberalisasi ekonomi sebagaimana yang terjadi dewasa ini, maka fungsi pemerintah secara umum dapat digolongkan dalam tiga jenis, yaitu, stabilisasi, distribusi, dan alokasi sumber ekonomi. Bidang stabilisasi meliputi stabiliasasi harga-harga, stabilisasi pertumbuhan ekonomi, dan sekaligus menjaga adanya kesempatan kerja. Karena wewenang kebijakan moneter dan fiskal tetap berada di Pusat, fungsi pemerintah daerah yang konvensional bisa absen dari ikut menjaga stabilisasi tersebut. Namun, pemerintah daerah sebenamya tetap memiliki andil dalam stabilisasi tersebut (Fisher, 1996). Lebih lagi di negara sedang berkembang yang menghadapi masalah yang lebih berat, pemerintah daerah bisa berperan lebih aktif dalam ikut menjaga terdapatnya kesempatan kerja. Pemerintah daerah memiliki asetaset yang dapat diarahkan untuk ikut menciptakan kesempatan kerja di daerah secara langsung. Umumnya hal ini terdiri dari penguatan pertanian, industri kecil, dan jasa-jasa yang bersifat self employment. Di samping itu, secara tidak langsung pemerintah daearah dapat membuat kebijaksanaan non fiskal dan moneter untuk 
menumbuhkan investasi dari dalam dan menarik investasi dari luar daerah. Kebijakan lokasi, keamanan, warga kota yang produktif, cinta kerja, dan seterusnya merupakan kebijakankebijakan non fiskal yang dapat mendorong investasi.

Dalam bidang redistribusi yang prinsipnya memungut dari si kaya dan dialokasikan kepada si miskin, pemerintah daerah memiliki kewenangan yang sangat terbatas sesuai dengan sistem perpajakan yang dianut. Akan tetapi pemerintah daerah memiliki asetaset, APBD, dan SDM yang dapat dialokasikan kepada rakyat miskin. Self employement_seperti pedagang kaki lima dan sejeisnya merupakan ciri khas, yang seyogyanya mendapatkan perhatian dalam setiap perencanaan pembangunan di daerah. Apabila perlu, peraturan daerah dapat dibuat mengenai peruntukan aset publik, seperti pasar, trotoar, dan sebagainya untuk membantu rakyat yang miskin dan memiliki semangat bekerja mandiri. Tidak perlu malu menjadi kota kaki lima, malah sebaiknya dijadikan ciri khas daerah. Ekonomi skala besar ternyata tidak menyelesaikan masalah, khususnya dalam hal pekerjaan dan melepaskan kemiskinan, bahkan ekonomi skala besar dan modern yang dibangun selama ini mendorong hutang negara yang besar dan menjadi penyebab krisis.

Dalam bidang alokasi sumbersumber, dimaksudkan adalah menjaga iklim kompetitif atau persaiangan sehat. Jika terjadi iklim yang tidak kompetitif, misalnya monopoli, pemerintah hendaknya masuk ke pasar. Tugas pemerintah adalah menjaga kompetisi yang fair. Pengertian fair di sini perlu disikapi oleh pemerintah daerah misalnya apakah persyaratan, harga untuk barang publik (misalnya sewa kios di pasar) sama untuk pemain besar dan kecil. Fair dalam pengeritian "barat" berarti kesamaan harga, tetapi fair dalam pengertian ini mungkin harga tidak harus sama, asalkan ditentukan secara transparan.

Singkatnya, proposal ini menganjurkan agar pemerintah daerah tidak hanya menjadi konvensional, yaitus menjadi pemerintah yang memfokuskan kepada 4 pilar fungsi utamanya (pendidikan, kesehatan, sosial welfare, dan tarnsportasi) dengan inovasi yang memadai. Akan tetapi, melangkah jauh dengan ikut mengambil tanggung jawab dalam ikut memecahkan masalah riil berupa pengangguran dan kemiskinan di daerahnya.

b. Menjadikan pengangguran sebagai sasaran utama. Pengangguran dewasa ini merupakan sumber kemerosotan mutu kehidupan sosial. Angka pengangguran diduga sangat tinggi, terutama jika diukur dari yang aktif mencari kerja maupun yang frustasi sehingga tidak terjun ke pasar kerja, dan yang setengah bekerja. Dengan tidak memiliki kewenangan fiskal, maka menjadikan pengangguran sebagai sasaran program daerah jangka panjang adalah tepat.

Pemerintah daerah perlu memulai dengan merumuskan kembali visi pemerintahannya yang umumnya menekankan kepada keindahan kota menjadi visi akan bemilainya "bekerja". Pemerintahan kota ditantang untuk melangkah lebih subtantif dalam memecahkan masalah masyarakat. Selanjutnya reformasi APBD mutlak diperlukan. Tidak terdapat reformasi apapun jika APBD masih merupakan tradisi yang tidak berubah strukturnya 
dari masa orde baru. SDM di pemerintahan kota perlu dibuat dalam divisidivisi baru yang berujung kepada pelayanan rakyat langsung dan mengurangi yang berada di belakang meja. Alihkan SDM menjadi guru (perbantukan opula ke sekolah swasta), perawat, penyuluh-penyuluh, dan sebagainya yang dirasakan loleh rakyat secara langsung. APBD yang menekankan admistratif dan tidak terfokus di reorientasi untuk mendukung pelayanan langsung tersebut. Lakukan income cutting khususnya anggaran admisnistratif untuk mendukung performa APBD yang menimbulkan kepercayaan rakyat.

c. Lakukan kebijakan mendorong investasi dari dalam dan menarik investasi dari luar. Pemerintah daerah jangan menjadi restriksi dengan pungutan bertarif tinggi untuk kebutuhan pemerintah. - Turunkan tarif-tarif untuk menggairah-kan bisnis, yang perlu ditingkatkan adalah pendapatan dan pekerjaan bagi masyarakat, dan bukannya PAD itu sendiri. Pada akhirnya dengan tarif menurun apabila tax base meningkat, maka total penerimaan pemerintah daerah justru akan meningkat. Tingkatkan keamanan, dan produktivitas, ciptakan masyarakat cinta dan hormat kepada bekerja sehingga menjadi prasyarat lahirnya industri-industri di kota itu.

\section{Penutup}

Proposal di atas menggambarkan pemerintahan daerah yang bergerak lebih substantif dalam memecahkan masalah masyarakatnya. Oleh karena itu diperlukan kesatuan visi antara pemerintah daerah dan DPRD akan perlunya pembaharuan, diperlukan moralitas yang tinggi dari sekedar dagang sapi dan meraih kepentingan sesaat, baru setelah itu diperlukan pengetahuan yang lebih teknis bagaimana mewujudkannya.

\section{Bacaan}

Fisher Ronald C. 1996, State and Local Public Finance. Chicago: Richard D. Irwin.

Hatsopoulus, N. and P.R. Krugman, 1990, U.S Competitiveness: Beyond the Trade Deficit. dalam P.King, International Economics and International Economic Policy: A Reader. New York: McGraw Hill.

I. Darmawan, Media Indonesia-Opini (11/ $16 / 00$ ).

Musgrave R.A. and Musgrave, P.B. 1984, - Public Finance in Theory and Practice. New York, McGraw Hill. 1984

Nurkholis, Akuntabilitas Publik dan Peran Akuntansi Pemerintahan Menyongsong Otonomi Daerah. tt.

Osborne, D. dan P. Plastrik (terj.), 2000. Memangkas Birokrási. Jakarta: PPM.

Osbome, D. dan T. Gabler 1999, (teri) Mewirausahakan Birokrasi. Jakarta: PPM.

Tirole, J. 1989, The Theory of Industrial Organization. London. MIT Press. 